\title{
Isolation and characterisation of virulent Serratia marcescens associated with a disease outbreak in farmed ornamental fish, Poecilia reticulata in Kerala, India
}

\author{
ARATHI DHARMARATNAM ${ }^{1}$, RAJ KUMAR ${ }^{1}$, V. S. BASHEER ${ }^{1}$, NEERAJ SOOD ${ }^{2}$, \\ T. RAJA SWAMINATHAN ${ }^{1 *}$ AND J. K. JENA ${ }^{3}$ \\ ${ }^{1}$ Peninsular and Marine Fish Genetic Resources Centre of ICAR-National Bureau of Fish Genetic Resources \\ P. B. No. 1603, Kochi - 682 018, Kerala, India \\ ${ }^{2}$ ICAR-National Bureau of Fish Genetic Resources, Canal Ring Road, P.O. Dilkusha, Lucknow - 226002 \\ Uttar Pradesh, India \\ Indian Council of Agricultural Research, KAB-II, Pusa, New Delhi-110 012, India \\ e-mail: rajathanga@yahoo.co.in
}

\begin{abstract}
Pathogenic strain of Serratia marcescens (NPSM-1) with multiple drug resistance was isolated from guppy Poecilia reticulata with clinical signs of fin rot and was confirmed by biochemical tests and $16 \mathrm{~S}$ rRNA gene sequencing. The extra cellular proteins (ECP) of the bacteria exhibited marked cytotoxic activity in vitro on Cyprinus carpio koi fin (CCKF) cell line. The in vivo challenge studies confirmed that the isolate was highly pathogenic to fish when the fishes were injected with $1 \times 10^{4} \mathrm{CFU} /$ fish and the same bacterium was re-isolated from infected fish, post-challenge. S. marcescens produced large zones of haemolysis on $10 \%$ sheep blood agar. The bacteria was found to carry virulence genes; extracellular metalloprotease gene (Pr596) and AHL synthase gene (SpnI). The bacterial isolate was tested to determine sensitivity against 16 antibiotics and was sensitive to only $5 \mathrm{viz}$., cefixime, chloramphenicol, ciprofloxacin, gentamycin and erythromycin. The study indicates that $S$. marcescens can cause disease in ornamental fish and the bacterium being a known human pathogen, may also cause infections in humans having direct contact with infected fishes. This is the first report describing S. marcescens as a pathogen of freshwater ornamental fish in India.
\end{abstract}

Keywords: Bacterial fish diseases, Guppy, Ornamental fish, Poecilia reticulata, Serratia marcescens

\section{Introduction}

Ornamental fish culture is one of the important and promising areas of aquaculture worldwide. In India, ornamental fish industry is expanding and is supported by government agencies such as the Marine Products Export Development Authority (MPEDA) (Silas et al., 2011). Diseases are inevitable with the rapid expansion of the aquaculture industry and pathogens have become one of the major bottlenecks to production. Variation in microbial community of water in the aquaculture systems is considered to be the major factor causing diseases and mortalities in fishes (Gomes, 1996). Austin et al. (1999) reported that higher quantities of organic material, changes in $\mathrm{pH}$ values and enhanced microbial populations resulted in infectious diseases in aquaculture.

The members of the family Enterobacteriaceae viz., Yersinia ruckeri, Edwardsiella tarda and E. ictaluri are recognised as fish pathogens (Sanders and Fryer, 1988). However, other enterobacteria such as Proteus sp., Citrobacter sp., Hafnia sp. and Serratia sp. have been associated with fish disease outbreaks (McIntosh and Austin, 1990). The genus Serratia comprising Serratia liquefaciens, S. marcescens and S. plymuthica have been associated with bacterial septicaemia and mortalities in salmonids (Austin and Gibb, 1993), though these species are considered opportunistic pathogens.

S. marcescens is a well known cause of hospital acquired infections, including nosocomial pneumonia, wound infections, urinary tract infections and septicaemia (Yu, 1979) and is a common microorganism present in soil and freshwater (Hejazi and Falkiner, 1997). Until now, there have been only a few publications concerning the fish infections caused by this microorganism. Baya et al. (1992) isolated $S$. marcescens from natural populations of white perch. Morone americanus, during the course of a bacteriological survey in USA. However, the emergence of multidrug resistant Serratia has been alarming not only in the medical field but also in aquaculture and agriculture sectors (Morohoshi et al., 2007). Recently S. marcescens has been isolated in an endemic disease outbreak from 
tilapia fish farms in Malaysia and its whole genome was sequenced (Chan et al., 2013). In the course of routine monitoring for diseases in ornamental fishes under the National Programme of Surveillance of Aquatic Animal Diseases (NSPAAD) in India, in June 2015, a farmer reported high mortality and morbidity in guppy, Poecilia reticulata with skin and fin rot lesions. The specimens were examined for important bacterial, viral and parasitic infections. We isolated a red pigmented bacterium which resembled $S$. marcescens from the affected fishes sampled from the farm. Because of the possible public health implications due to these bacteria, we aimed to characterise this microorganism; to determine whether $S$. marcescens is really the causative agent of such health disorders in guppy fish; and to select the most suitable antibiotic agent for the treatment of fishes affected by this bacterium.

\section{Materials and methods}

\section{Fish sampling}

The ornamental fish farmer from Kozhikode, Kerala reported several incidences of mortality in guppies (body weight range : 0.45 to $0.80 \mathrm{~g}$ ) with fin and tail rot and mortality up to $40 \%$ during the rainy season (June-August) in 2015, with a history of not responding to antibacterial, antiparasitic and antiprotozoan treatments. Diseased $(n=25)$ fish were collected from the farm for detailed investigations. All fish were transported to the laboratory on ice within 6 h. The tissues viz., fin, gills, spleen and kidney from the affected fish were stored in $95 \%$ ethanol and Leibovitz's L-15 tissue culture medium for screening of viruses viz., Koi Herpes virus (KHV), Iridovirus and spring viraemia of carp virus (SVCV) as described by Kumar et al. (2015) and isolation of viral pathogen, if any, respectively. A tissue homogenate was prepared from the pooled samples of fin, gills, spleen, heart and kidney from the affected fish and inoculated on different fish cell lines viz., pearl spot fin (PSF) (Swaminathan et al., 2010), catopra fish fin (CFF) (Swaminathan et al., 2013), Horabagrus brachysoma fin (HBF) (Swaminathan et al., 2014), Cyprinus carpio koi fin (CCKF) (Swaminathan et al., 2015), angelfish fin (AFF) (Swaminathan et al., 2016) and goldfish fin (GFF) (unpublished) maintained in our laboratory to screen for viral infections. The scrapings from skin, fin and gills of the affected fish were collected and examined under microscope for external parasitic infestation.

\section{Bacterial isolation}

For bacterial isolation, whole fish was homogenised in sterile phosphate buffered saline (PBS) in the ratio of 1:1 (w/v) and inoculated into trypticase soy agar (TSA;
Himedia, India). The cultures were incubated at $28^{\circ} \mathrm{C}$ for 48-72 $\mathrm{h}$ and the number and diversity of colonies were determined. Preliminary tests allowed us to identify the dominant red pigmented colonies isolated from guppy as Serratia sp. and biochemical tests were conducted following procedures described by Barrow and Feltham (2004). Pure cultures were kept frozen at $-80^{\circ} \mathrm{C}$ in double strength tryptic soy broth supplemented with $15 \%$ glycerol for further examination. For the taxonomic analysis, the reference strains of $S$. marcescens ATCC 1800 and $S$. marcescens isolated from natural populations of white perch, Morone americana (Baya et al., 1992) were included for comparison.

PCR amplication of $16 \mathrm{~S}$ rRNA, metalloprotease and quorum sensing genes of $S$. marcescens

S. marcescens isolate was further confirmed by sequence analysis of $16 \mathrm{~S}$ rRNA gene, extracellular metalloprotease gene (Pr596) and AHL synthase gene (SpnI) (Tao et al., 2007; Tariq, 2010). Total genomic DNA was isolated from pure bacterial cultures using the DNeazy blood and tissue kit (Qiagen) following the manufacturer's instructions. The DNA concentration was quantified with a bio-spectrophotometer (Eppendrof, Germany) and adjusted to a concentration of $100 \mathrm{ng} \mu^{-1}$. Universal primers 27F (5-AGAGTTTGATCCTGGCTCAG-3) and 1492R (5-TACGGCTACCTTGTTACGACTT-3), were used to amplify the 16S rRNA gene (Weisburg et al., 1991). The PCR products were sequenced at an automated sequencing facility (Scigenom Pvt. Ltd, India). The raw DNA sequences were edited using BioEdit sequence alignment editor version 7.0.5.2 (Hall, 1999). For molecular identification, homology comparison of $16 \mathrm{~S}$ rRNA sequences of bacterial strains was performed using Basic Local Alignment Search Tool (BLAST) and Ribosomal Database Project (RDP). The sequences were compared for similarity between the sequences of collected bacterial isolates and the sequences available at GenBank and a phylogenetic tree was constructed by neighbourjoining method. Distance matrices were calculated using Kimura's 2-parameter correction and stability of groupings and bootstrap analysis (1000 replicates) was conducted using MEGA 5.05 software (Tamura et al., 2011). Vibrio cholerae (GenBank Accession No. LC011458) was used as an out group. Additionally, two sequences of S. marcescens previously submitted to GenBank (Accession nos. AY498856 and EF194094) and other Serratia sp. viz., S. liquefaciens, $S$. plymuthica, $S$. odorifera, $S$. glossinae and S. ficania were included in phylogenetic analysis. The partial $16 \mathrm{~S}$ rRNA, Pr596 and SpnI gene sequences of $S$. marcescens isolate were deposited in the GenBank database. 


\section{Heamolytic activity}

S. marcescens produces a variety of virulence proteins, including heamolysin, which was reported to be the dominant virulence factor of the bacterium. The strain was tested for haemolysis activity on blood agar containing $10 \%$ sheep erythrocytes. Tryptone-yeast extract (TY) base (HiMedia, India) was used to prepare blood agar plates. The bacterial suspensions were streaked on to the plates and plates were evaluated initially after incubation for $24 \mathrm{~h}$ at $28^{\circ} \mathrm{C}$ and after further incubation for $12 \mathrm{~h}$ at $4^{\circ} \mathrm{C}$. A clear and colourless zone around the colony indicates $\alpha$-haemolytic activity.

\section{Challenge tests}

The bacteria, $S$. marcescens was grown in trypticase soya broth for $24 \mathrm{~h}$ at $28^{\circ} \mathrm{C}$ and then centrifuged at $2000 \mathrm{~g}$ for $10 \mathrm{~min}$ and cell pellets were suspended in sterile PBS to the final concentration of $1 \times 10^{5}$ cells $\mathrm{ml}^{-1}$. Healthy guppies weighing $0.50-0.75 \mathrm{~g}$ were used in challenge experiments. Before infection, the fish were anaesthetised with MS-222 (Sigma). For each bacterial strain, 10 guppy fish were injected intraperitoneally (i/p) with $100 \mu$ of the bacterial suspension for testing Koch's postulates and the same number of fishes were injected with sterile PBS, which were treated as the controls. Fishes were maintained in 1001 capacity glass aquaria with 501 water with continuous aeration, daily $50 \%$ exchange of water and ad libitum feeding. The challenged fish were observed daily for infection after inoculation with $S$. marcescens bacterial suspension. Infected fish were examined, bacteria reisolated and reconfirmed by biochemical tests, PCR and sequencing as mentioned above.

\section{Antibiotic sensitivity tests}

S. marcescens isolates were tested for antibiotic susceptibility using disc diffusion method on Mueller Hinton Agar (Himedia, India) (Bauer et al., 1966). A total of sixteen antibiotics (HiMedia, India) were tested: ampicillin $\left(25 \mu \mathrm{g} \mathrm{disc}{ }^{-1}\right)$, gentamycin $\left(120 \mu \mathrm{g} \mathrm{disc} \mathrm{din}^{-1}\right)$, oxytetracycline $\left(30 \mu \mathrm{g} \mathrm{disc} c^{-1}\right)$, cefalexin $\left(30 \mu \mathrm{g} \mathrm{disc}^{-1}\right)$, chloramphenicol $\left(25 \mu \mathrm{g} \mathrm{disc}{ }^{-1}\right)$, ciprofloxacin $\left(30 \mu \mathrm{g}^{-1}\right.$ disc), cefixime $\left(5 \mu \mathrm{g} \operatorname{disc}^{-1}\right)$, kanamycin $\left(30 \mu \mathrm{g} \mathrm{disc}^{-1}\right)$, nitrofurantoin $\left(100 \mu \mathrm{g} \mathrm{disc}{ }^{-1}\right)$, erythromycin $\left(10 \mu \mathrm{g} \mathrm{disc}^{-1}\right)$, amoxicillin $\left(25 \mu \mathrm{g} \mathrm{disc}^{-1}\right)$, furazolidone $\left(100 \mu \mathrm{g} \mathrm{disc}^{-1}\right)$, bacitracin $\left(10 \mu \mathrm{g} \mathrm{disc} c^{-1}\right)$, azithromycin $\left(30 \mu \mathrm{g} \mathrm{disc}{ }^{-1}\right)$, enrofloxacin $\left(10 \mu \mathrm{g} \mathrm{disc}^{-1}\right)$ and cefixime/ clavulanic acid $\left(5 / 10 \mu \mathrm{g} \mathrm{disc}^{-1}\right)$. Antibiotic sensitivity was assayed from the diameter of zone of inhibition formed around the discs. Manufacturer's instructions were used to determine the sensitivity as sensitive, intermediate and resistant to antibiotics.

\section{Cytotoxicity study}

The extracellular product (ECP) of $S$. marcescens was obtained by the cellophane plate technique (Liu, 1957). Briefly, sterile cellophane tape was placed on TSA plates and inoculated by spreading $0.5 \mathrm{ml}$ of broth culture of $S$. marcescens over the surface with sterile swab. After incubation at $28^{\circ} \mathrm{C}$ for $24 \mathrm{~h}$, bacterial cells were washed off the cellophane with PBS. The cell suspension was centrifuged at $400 \mathrm{~g}$ for $30 \mathrm{~min}$ at $4{ }^{\circ} \mathrm{C}$ and the resulting supernatant was filtered using $0.45 \mu \mathrm{m}$ syringe filter and stored at $-80^{\circ} \mathrm{C}$ until required. The cytotoxicity of ECP was assessed on CCKF cell line (Swaminathan et al., 2015 ) in duplicate in 6-well plates and control wells were inoculated with sterile phosphate buffered saline (PBS). For this purpose, the ECP of the isolate was inoculated and observed at regular intervals (every $6 \mathrm{~h}$ ) by inverted microscopy for signs of cytotoxicity for up to 7 days post-infection.

\section{Results and discussion}

A total number of 20 infected fish from the affected ornamental fish farm were examined in this study. Affected fish were initially examined and most of the individuals showed clinical signs such as emaciation of body, distended anus, discoloration of the body and fin rot. Screening using molecular tools revealed that the fish samples were free from koi herpes virus (KHV), spring viraemia virus (SVCV) and iridovirus. No cytopathic effects (CPE) could be detected in any of the fish cell lines viz., RTF, HBF, CFF, PSF, PFF, CCKF and GFF, inoculated with the tissue filtrate even after 15 days post-inoculation (dpi). Moreover, even occasional parasites such as Trichodina sp., Dactylogyrus sp. or Gyrodactylus sp. were not observed in the affected fish.

Putative characteristic red pigment producing colonies for Serratia species were isolated from diseased guppies along with other bacterial colonies. Serratia marcescens on TSA (Fig. 1) constituted $85-90 \%$ of total bacterial flora in samples from individual fish showing clinical signs of disease and remaining $10-15 \%$ colonies were identified as Bacillus sp. The characteristics of the isolates were: Gram negative motile rods, fermentative, oxidase and catalase negative, indole negative, Voges-Proskauer and nitrate positive, arginine dehydrolase negative but lysine and ornithine positive with gas production from glucose but not $\mathrm{H}_{2} \mathrm{~S}$. Other morphological and biochemical characteristics are described in Table 1. These properties, together with the carbohydrate fermentation pattern, are similar to those exhibited by the reference strain of $S$. marcescens ATCC 8100 and white perch isolate $S$. marcescens (RB 469) (Baya et al., 1992). Results of biochemical tests of the red 


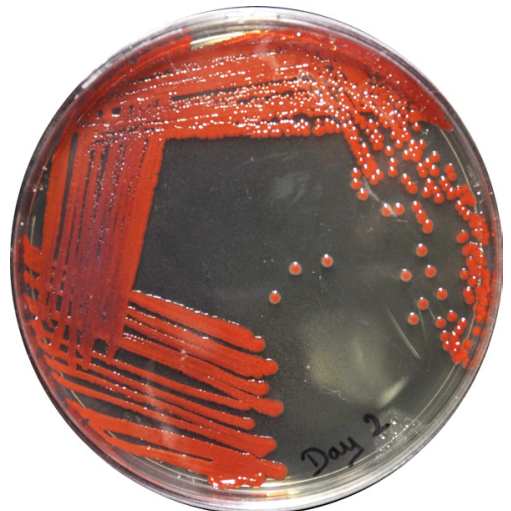

Fig. 1. Typical red pigment colonies of Serratia marcescens (NPSM-1) isolated from fin rot lesions in guppy, Poecilia reticulata

pigmented bacteria revealed that it is an enterobacteria belonging to the species $S$. marcescens (NPSM-1).

According to Austin and Austin (2007), bacteria such as Aeromonas sp., Bacillus sp., Citrobacter sp., Edwardsiella sp., Flavobacterium sp., Klebsiella sp., Proteus sp., Providencia sp. and Serratia sp, are associated with fish disease and several bacterial pathogens have been isolated from freshwater fish by various workers (Kumar and Dey, 1988; Das et al., 1999; Novotny et al., 2004; Mohanty and Sahoo, 2007) in India. Recently Kumar et al. (2015) isolated a zoonotically important bacterial pathogen; Proteus hauseri causing mass mortality of ornamental koi carp in India. S. marcescens was isolated and confirmed only by biochemical characteristics from marine ornamental fish with ulcerative disease in India (Pramila, 2002). In the present study S. marcenscens was isolated and identified from diseased guppy fish P. reticulata.

Sequence analysis of $16 S \mathrm{rRNA}$, metalloprotease and quorum sensing genes of $S$. marcescens

Approximately $1470 \mathrm{bp}$ gene sequence of 16S rRNA was amplified after assembling the forward and reverse sequences. The $1408 \mathrm{bp}$ and $1486 \mathrm{bp}$ of metalloprotease gene (Pr596) and AHL synthase gene (SpnI) were also amplified and sequenced (Fig. 2). The BLAST results of 16S rRNA gene, Pr596 and SpnI showed that the isolate shared 99.5, 98 and 99\% similarity respectively with $S$. marcescens. This is the first description of $S$. marcescens strains as pathogens of guppy Poecilia reticulata. To date, only limited scientific reports on Serratia sp. associated fish diseases are documented. Nieto et al. (1990) isolated $S$. plymuthica from moribund rainbow trout in north-western Spain, McIntosh and Austin (1990) isolated bacteria resembling $S$. liquefaciens from salmonids in Australia and Scotland and Baya et al. (1992) isolated
Table 1. Biochemical characteristics of Serratia marcescens (NPSM-1) bacterial strains isolated from guppy mass mortality in this study

\begin{tabular}{|c|c|c|c|}
\hline Biochemical tests & $\begin{array}{l}\text { S. marcescens } \\
\text { (NPSM-1) } \\
\text { isolated in } \\
\text { this study }\end{array}$ & $\begin{array}{l}\text { S. marcescens } \\
\text { ATCC } 8100\end{array}$ & $\begin{array}{l}\text { S. marcescens } \\
\text { isolated from } \\
\text { experimentally } \\
\text { challenged fish }\end{array}$ \\
\hline Gram stain & -- & - & - \\
\hline Motility & + & + & + \\
\hline Oxidase & - & - & - \\
\hline Catalase & + & + & + \\
\hline $\begin{array}{l}\text { Oxidative/ } \\
\text { Fermentative glucose }\end{array}$ & $\mathrm{F}$ & $\mathrm{F}$ & $\mathrm{F}$ \\
\hline Methyl red & - & - & - \\
\hline Voges-Proskauer & + & + & + \\
\hline Indole production & - & - & - \\
\hline Nitrate reduction & + & + & + \\
\hline Citrate utilisation & + & - & + \\
\hline Growth at $15^{\circ} \mathrm{C}$ & + & + & + \\
\hline Growth at $25^{\circ} \mathrm{C}$ & + & + & + \\
\hline Growth at $37^{\circ} \mathrm{C}$ & + & + & + \\
\hline Growth at $0 \% \mathrm{NaCl}$ & + & + & + \\
\hline Growth at $3 \% \mathrm{NaCl}$ & + & + & + \\
\hline Growth at $6 \% \mathrm{NaCl}$ & + & + & + \\
\hline Arginine decarboxylase - & - & - & - \\
\hline Lysine decarboxylase & + & + & + \\
\hline Ornithine decarboxylase & & - & + \\
\hline Haemolysis on sheep & $\beta$ & $\beta$ & $\beta$ \\
\hline
\end{tabular}

blood agar

Sugar utilisation

$\begin{array}{llll}\text { Mannose } & + & + & + \\ \text { Galactose } & + & + & + \\ \text { Fructose } & + & + & + \\ \text { Maltose } & + & + & + \\ \text { Sucrose } & + & + & + \\ \text { Rahmnose } & - & - & - \\ \text { Arabinose } & - & - & - \\ \text { Salicin } & + & + & + \\ \text { Trehalose } & + & + & + \\ \text { Lactose } & - & - & - \\ \text { Xylose } & - & - & - \\ \text { Cellobiose } & - & - & - \\ \text { Raffinose } & - & - & - \\ \text { Mannitol } & + & + & + \\ \text { Sorbitol } & + & + & +\end{array}$

S. marcescens from white perch, Morone americanus in USA. Although the origin of the $S$. marcescens in the diseased guppy is not known, it is possible that the bacteria may have originated from one of the farm personnel in close contact with the fish. $S$. marcescens is a well known human pathogen causing respiratory tract and urinary tract infection as well as endocarditis, osteomyelitis, pneumonia and meningitis (Hejazi and Falkiner, 1997). 


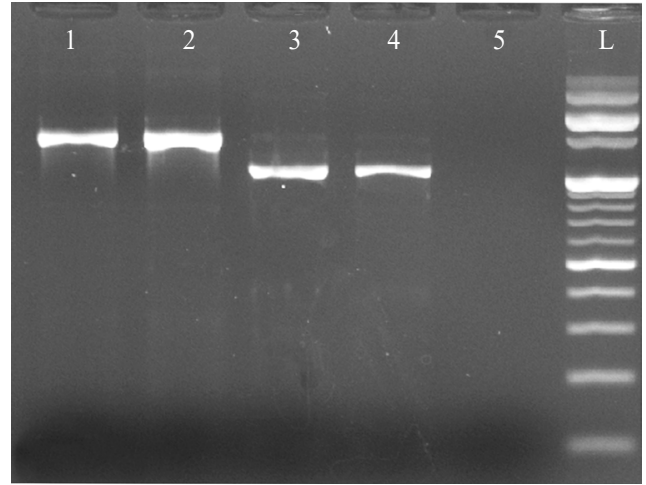

Fig. 2. Agarose gel image showing PCR-amplified 1408 bp and 1486 bp bands of metalloprotease gene (Pr596) from Serratia marcescens (NPSM-1)

Lanes 1 and 2 - metalloprotease gene (Pr596); Lanes 3 and 4 - AHL synthase gene $(S p n I)$; Lane 5 - DNA template from Aeromonas hydrophila as negative control. Lane L: Low range DNA ruler, $100 \mathrm{bp}$ to $3 \mathrm{kbp}$ (GeNei)

Extracellular metalloproteases, Pr596 are mostly associated with pathogenic bacteria or bacteria that have industrial significance (Hase and Finkelstein, 1993). Many Gram negative pathogens control the expression of virulence factors, secretion of extracellular protease, pectinase and rhamnolipid and biofilm formation via the quorum-sensing system (de Kievit and Iglewski, 2000). The regulation of flagellum independent populational surface migration, the synthesis of biosurfactant and production of prodigiosin and nuclease in $S$. marcescens SS-1 are co-ordinately negatively monitored by spnIR
(Horng et al., 2002). It has been shown that Serratia strains employ quorum sensing for the regulation of genes encoding extracellular virulence factors. In Serratia, at least four different LuxRI/AHL quorum sensing systems viz., SprIR from Serratia proteamaculans, SwrIR from Serratia liquefaciens MG1 (now renamed as $S$. marcescens MG-1) SpnIR from S. marcescens SS-1 and SmaIR from Serratia sp. ATCC39006 have been described (Wei and Lai, 2006).

\section{Phylogenetic tree}

The phylogenetic tree was constructed based on $1450 \mathrm{bp}$ of $16 \mathrm{~S}$ rRNA gene sequences (Fig. 3). The $16 \mathrm{~S}$ rRNA sequence of NPSM-1 was compared with published sequences of $S$. marcescens and sequences of other species viz., S. liquefaciens, S. plymuthica, S. odorifera, $S$. glossinae and $S$. ficania. Distantly related bacteria $V$. cholerae was taken as outgroup. It generated clusters, which were supported by bootstrap values of 93 and 100 .

\section{Haemolytic assay}

S. marcescens produces a range of secreted products, including lipases, proteases, chitinases, nucleases, biosurfactants and haemolysin (Hejazi and Falkiner, 1997). In our study, when $S$. marcescens colonies were spotted on $10 \%$ sheep blood agar, they did not form haemolysis zones at $24 \mathrm{~h}$ of incubation at $28^{\circ} \mathrm{C}$, but after incubation for an additional $12 \mathrm{~h}$ at $4^{\circ} \mathrm{C}$ the haemolytic zones were observed (Fig. 4). Haemolysin production is a common attribute of $S$. marcescens strains and has been shown to be involved in the virulence of this pathogen

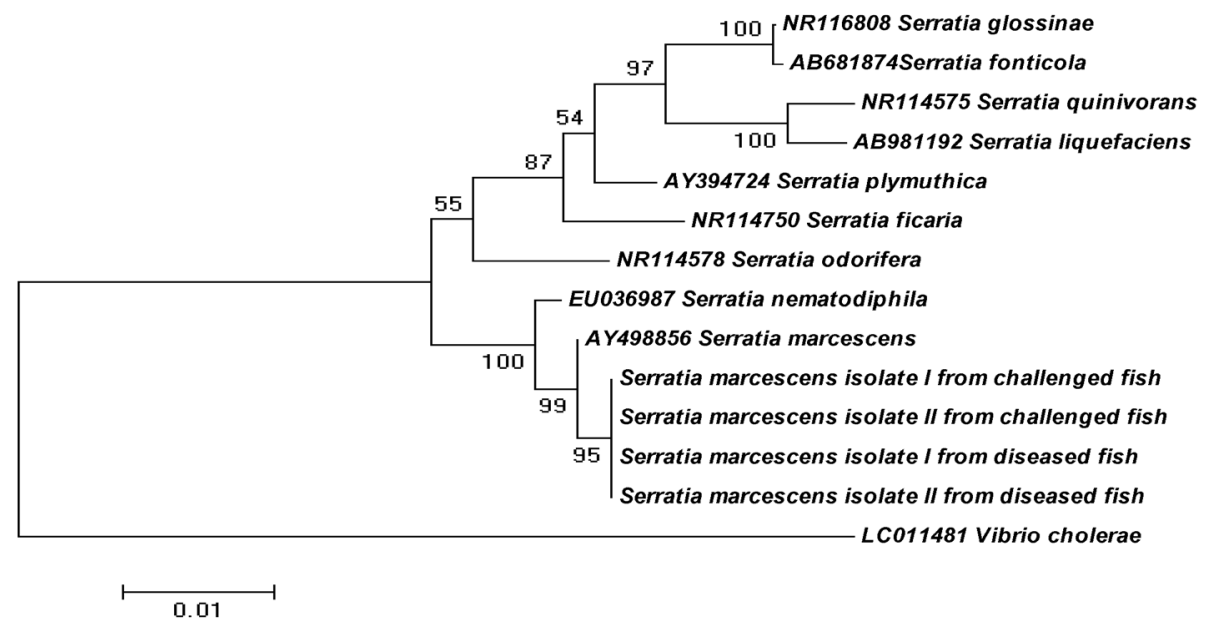

Fig. 3. Phylogenetic tree based on the concatenated sequences of 16S rRNA of Serratia marcescens (NPSM-1) isolated from guppy and related Serratia species. The neighbour-joining algorithm was used to construct the tree with genetic distance computed by Kimura's 2-parameter method. Bootstrap values of 1000 simulations are indicated at the branches. The bar indicates percentage difference 


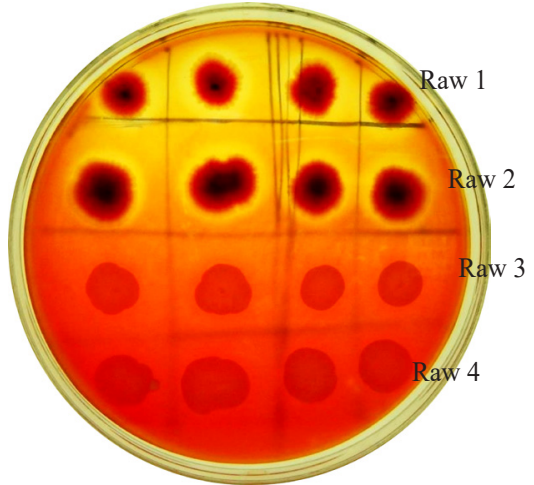

Fig. 4. Haemolysis of sheep erythrocytes on $10 \%$ sheep blood agar plates after $24 \mathrm{~h}$ of incubation at $28^{\circ} \mathrm{C}$ and further incubation at $4^{\circ} \mathrm{C}$ for $12 \mathrm{~h}$.

Row 1 and 2 - isolates of Serratia marcescens (NPSM-1) showing swarming growth and zones of haemolysis, Row 3 and 4 - colonies of non-haemolytic Aeromonas sp.

(Hilger and Braun, 1995). S. marcescens secretes a haemolysin that also acts as a cytotoxin and the haemolytic activity is determined by the $s h l \mathrm{~A}$ and $s h l \mathrm{~B}$ genes (Poole et al., 1988). In the absence of $S h l \mathrm{~B}$, inactive ShlA of $S$. marcescens remains in the periplasm and displays less haemolytic activity with small haemolysis zone (Schiebel et al., 1989).

\section{Cytotoxicity}

The ECP from the NPSM-1displayed a positive cytotoxic response on the CCKF cell line tested within $24 \mathrm{~h}$. The cytotoxic changes started appearing in the CCKF cells within $6 \mathrm{~h}$ post-inoculation (hpi) and followed by lysis of cells after 24 hpi. No morphological changes could be detected in the control cells inoculated with PBS. Cytotoxic changes viz., granulation, vacuolation, rounding and dislodgement of cells, were recorded on microscopic examination of the infected CCKF cell line (Fig. 5a, b, $\mathrm{c}$ and d). Vacuoles in different epithelial cell lines viz., adherent HEp-2, RT112, HeLa, Chang and Hec1B cells were observed when treated with supernatant culture of S. marcescens within $15 \mathrm{~min}$, followed by lysis after 40 min (Hertle et al., 1999). A similar cytotoxic change to that of ShlA - induced vacuolation has been observed with aerolysin from Aeromonas hydrophila (Abrami et al., 1998). S. marcescens exerts haemolytic and vacuolating cytotoxic activities mainly in direct contact with the different target cells (Braun et al., 1985).

\section{Antibiotic sensitivity}

The susceptibility of $S$. marcescens to antibacterial agents varied. The bacteria was resistant to ampicillin, amoxicillin, cefalaxein, furazolidone, kanamycin, nitrofuratoin and oxtetracycline while susceptible to cefixime, chloramphenicol, ciprofloxacin, erythromycin and gentamycin. Similar observations concerning S. marcescens isolated from clinical cases of marine and freshwater fish were also previously described (Baya et al., 1992). Resistance of $S$. marcescens to 11 out of 16 tested antimicrobial agents was observed. This suggests development of multidrug resistance by this bacteria and need for identifying appropriate antibiotic treatment against this bacterium, supported by antibiotic susceptibility testing. The fish farmer was advised to administer ciprofloxacin in the feed to affected fish at the dose rate of $5 \mathrm{mg} \mathrm{g}^{-1}$ feed twice daily for five days. After administering the antibiotic, fish recovered from the disease and no further mortality of guppy was noticed in the farm.

\section{Experimental challenge tests}

Fish infected with NPSM-1showed the following external signs viz., dark skin, necrotic skin lesions and fin rot. S. marcescens was reisolated in pure cultures from infected fish. No mortality or any disease signs were observed in fish injected with sterile PBS. The mortality

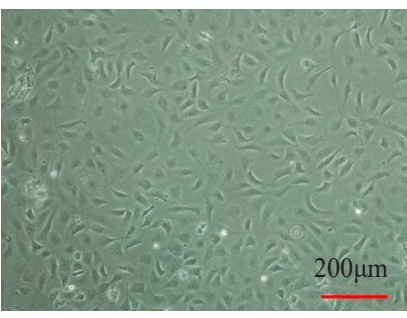

(a)

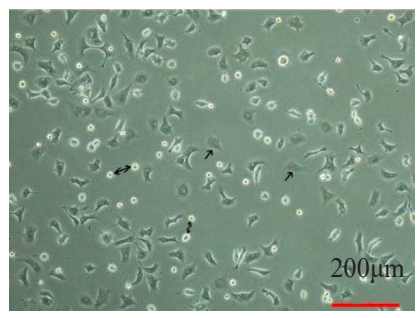

(b)

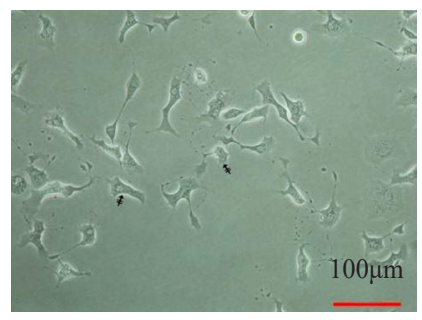

(c)

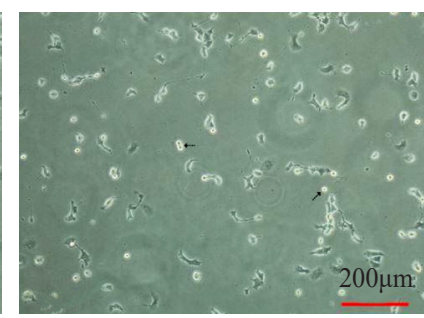

(d)

Fig. 5. Phase-contrast photomicrographs of Serratia marcescens (NPSM-1) ECP-induced cytotoxic changes of CCKF cells. (a) Control; (b) $6 \mathrm{~h}$ post inoculation (hpi); (c), $12 \mathrm{hpi}$; (d) $24 \mathrm{hpi}$. After incubation at $28^{\circ} \mathrm{C}$, cells were examined by phasecontrast microscopy. Cytotoxicity changes viz., granulation $(\leftarrow-$ arrow), vacuolation ( $\ddagger$ - crossed arrow), rounding $(\leftrightarrow \quad$ - double sided arrow) and dislodgement $(\cdots \quad$ - dotted arrow) of CCKF cells were recorded subsequent to the addition of ECPs of S. marcescens (NPSM-1) 
rate of the experimentally challenged group was 55\% as reported in earlier studies (Baya et al., 1992). In this study, the reisolation of $S$. marcescens from freshly dead experimental fish and its confirmation by sequencing fulfilled Koch's postulates. The results suggest that the present $S$. marcescens strain could be considered a potential bacterial pathogen for fish.

It has been demonstrated (Buras et al., 1985) that a high bacterial load in water, stresses the fish immune system and result in invasion and proliferation of environmental bacteria in the fish tissues. There is a possibility for dissemination of $S$. marcescens to other geographic areas through the water and fish trade. Chan et al. (2013) isolated S. marcescens W2.3, a suspected causal agent of an endemic disease outbreak along with other bacteria from the tilapia fish farms of Malaysia during 2009. The emergence of multidrug resistant Serratia sp., has been distressing in the human medical field and also in aquaculture and agriculture sectors (Kurz et al., 2003). In addition, the potential pathogenic capability and multidrug resistance of this isolate may be of public health concern since $S$. marcescens is a well recognised opportunistic pathogen causing important human infections.

The isolation of the highly virulent and multidrug resistant zoonotically important bacterium $S$. marcescens, from freshwater ornamental fish in India poses a threat that this pathogen could cause infections to the farm personnel. This may be given due attention as they might cause zoonotic diseases. Further epidemiological investigations together with studies on $S$. marcescens pathogenicity are necessary to elucidate the public health significance of $S$. marcescens.

\section{Acknowledgements}

The authors are thankful to the Secretary, Department of Agricultural Research and Education and Director General, Indian Council of Agricultural Research and DDG (Fy) ICAR, New Delhi, India for their support, encouragement and guidance. We thank National Fishery Development Board, Ministry of Agriculture. Government of India for their financial support.

\section{References}

Abrami, L., Fivaz, M., Glauser, P. E., Parton, R. G. and Van-der-Goot, F. G. 1998. A pore-forming toxin interacts with a GPI-anchored protein and causes vacuolation of the endoplasmic reticulum. J. Cell. Biol., 140(3): 525-540.

Austin, B. and Gibb, A. 1993. Emerging bacterial fish pathogens and their likely significance for aquaculture. Proceedings of the first international symposium on aquaculture technology and investment opportunities. Ministry of Agriculture and Water, Riyadh, Saudi Arabia, p. 410-425.

Austin, B. and Austin, D. 2007. Bacterial fish pathogens: Diseases of farmed and wild Fish. $4^{\text {th }}$ edn. Praxis Publishing Ltd., Chichester, UK.

Austin, B., Stewart Tull, D. E. S., Dennis, P. J. and Godfree, J. A. F. 1999. The effects of pollution on fish health. J. Appl. Microbiol., 85: 234-242.

Barrow, G. I. and Feltham, R. K. A. 2004. Cowan and Steel's manual for the identification of medical bacteria. Cambridge University Press.

Bauer, A. W., Kirby, W. M., Sherris, J. C. and Turck, M. 1966. Antibiotic susceptibility testing by a standardised single disk method. Am. J. Clin. Pathol., 45(4): 493-496.

Baya, A., Toranzo, A., Lupiani, B., Santos, Y. and Hetrick, F. 1992. Serratia marcescens: a potential pathogen for fish. J. Fish. Dis., 15(1): 15-26.

Braun, V., Gunther, H., Neuss, B. and Tautz, C. 1985. Hemolytic activity of Serratia marcescens. Arch. Microbiol., 141(4): 371-376.

Buras, N., Duek and Niv, S. 1985. Reactions of fish to microorganisms in waste water. Appl. Environ. Microbiol., 50(4): 989-995.

Chan, X. Y., Chang, C. Y., Hong, K. W., Tee, K. K., Yin, W. F. and Chan, K. G. 2013. Insights of biosurfactant producing Serratia marcescens strain W2.3 isolated from diseased tilapia fish: a draft genome analysis. Gut. Pathog., 5(1): 29.

Das, B. K., Mukherjee, S. C., Sahuand, B. B. and Murjani, G. 1999. Neem (Azadirachta indica) extracts as an antibacterial agent against fish pathogenic bacteria. Indian J. Exp. Biol., 37: 1097-1100.

De Kievit, T. R. and Iglewski, B. H. 2000. Bacterial quorum sensing in pathogenic relationships. Infect. Immun., 68(9): 4839-4849.

Gomes, L. A. 1996. Can marine ornamental fish be farm raised? Infofish Int., (3/96): 27-32.

Hall, T. A. 1999. BioEdit: a user-friendly biological sequence alignment editor and analysis program for Windows 95/98/ NT. Nucl. Acids. Symp. Ser., 41: 95-98.

Hase, C. C. and Finkelstein, R. A. 1993. Bacterial extracellular zinc containing mettaloproteases. Microbiol. Rev., 57(4): 823-837.

Hejazi, A. and Falkiner, F. R.1997. Serratia marcescens. J. Med. Microbiol., 46(11): 903-912.

Hertle, R., Hilger, M., Weingardt-Kocher, S. and Walev, I. 1999. Cytotoxic action of Serratia marcescens hemolysin on human epithelial cells. Infect. Immun., 67(2): 817-825. 
Hilger, M. and Braun, V. 1995, Superlytichemolysin mutants of Serratia marcescens. J. Bacteriol., 177(24): 7202-7209.

Horng, Y. T., Deng, S. C., Daykin, M., Soo, P. C., Wei, J. R., Luh, K. T., Ho, S. W., Swift, S., Lai, H. C. and Williams, P. 2002. The LuxR family protein SpnR functions as a negative regulator of $\mathrm{N}$-acylhomoserine lactone-dependent nquorum sensing in Serratia marcescens. Mol. Microbiol., 45(6): 1655-1671.

Kumar, D. and Dey, R. K. 1988. Bacterial septicaemia in silver carp, Hypophthalmichthys molitrix (Val.) Veterinariski. Archiv., 58(6): 277-83.

Kumar, R., Swaminathan, T. R., Dharmaratnam, A., Basheer, V. S. and Jena, J. K. 2015. Mass mortality in ornamental fish, Cyprinus carpio koi caused by a bacterial pathogen, Proteus hauseri. Acta. Trop., 14: 128-134.

Kurz, C. L., Chauvet, S., Andres, E., Aurouze, M., Vallet, I., Michel, G. P., Uh, M., Celli, J., Filloux, A. and De Bentzmann, S. 2003. Virulence factors of the human opportunistic pathogen Serratia marcescens identified by in vivo screening. EMBO J., 22(7): 1451-1460.

Liu, P.V. 1957. Survey of haemolysin production among species of Pseudomonas. J. Bacteriol.,74(6): 718-727.

McIntosh, D. and Austin, B. 1990. Recovery of an extremely proteolytic form of Serratia liquefaciens as a pathogen of Atlantic salmon. Salmo salar, in Scotland. J. Fish. Biol., 36(5): 765-772.

Mohanty, B. R. and Sahoo, P. K. 2007. Edwardsiellosis in fish: a brief review. J. Biosci., 32(3): 1331-1344.

Morohoshi, T., Shiono, T., Takidouchi, K., Kato, M., Kato, N., Kato, J. and Ikeda, T. 2007. Inhibition of quorum sensing in Serratia marcescens AS-1 by synthetic analogs of $\mathrm{N}$-acylhomoserine lactone. Appl. Environ. Microbiol., 73(20): 6339-6344.

Nieto, T. P., Lopez, L. R., Santos, Y., Nunez, S. and Toranzo, A. E. 1990. Isolation of Serratia plymuthica as an opportunistic pathogen in rainbow trout, Salmo gairdneri Richardson. $J$. Fish. Dis., 13(2): 175-177.

Novotny, L., Dvonska, L., Lorencova, A., Beran, V. and Pavlik, L. 2004. Fish: A potential source of bacterial pathogens for human beings. Vet. Med. Czech., 49(9): 343-358.

Poole, K., Schiebel, E. and Braun, V. 1988. Molecular characterisation of the hemolysin determinant of Serratia marcescens. J. Bacteriol., 170(7): 3177-3188.

Pramila, S. 2002. Bacterial diseases and their management in chosen marine ornamental fishes. Ph. D. thesis, Central Institute of Fisheries Education, Mumbai, India.

Sanders, J. E. and Fryer, J. L. 1988. Bacteria of fish. In: Austin, B. (Ed.), Methods in aquatic bacteriology, John Wiley and Sons Ltd., Chichester, p. 115-142.

Schiebel, E., Schwarz, H. and Braun, V. 1989. Subcellular location and unique secretion of the heamolysin of Serratia marcescens. J. Biol. Chem., 264(27): 16311-16320.
Silas, E. G., Gopalakrishnan, A., Ramachandran, A., Anna Mercy, T. V., Kripan Sarkar, Pushpangadan, K. R., Anil Kumar, P., Ram Mohan, M. K. and Anikuttan, K. K. 2011. Guidelines for green certification of freshwater ornamental fish. Marine Products Export Development Authority, Kochi, India.

Swaminathan, T. R., Lakra, W. S., Gopalakrishnan, A., Basheer, V. S., Khushwaha, B. and Sajeela, K. A. 2010. Development and characterisation of a new epithelial cell line PSF from caudal fin of Green chromide, Etroplus suratensis (Bloch, 1790). In Vitro. Cell. Dev. Biol. Anim., 46(8): 647-56.

Swaminathan, T. R., Basheer, V. S., Gopalakrishnan, A., Rathore, G., Chaudhary, D. K., Raj Kumar and Jena, J. K. 2013. Establishment of caudal fin cell lines from tropical ornamental fishes Puntius fasciatus and Pristolepis fasciata endemic to the Western Ghats of India. Acta. Trop., 128(3): 536-541.

Swaminathan, T. R., Basheer, V. S., Gopalakrishnan, A., Sood, N. and Pradhan, P. K. 2014. A new epithelial cell line, HBF from caudal fin of endangered yellow catfish, Horabagrus brachysoma (Gunther, 1864). Cytotechnology., 68(3): 515-523.

Swaminathan, T. R., Basheer, V. S., Raj Kumar, Kathirvelpandian, A., Sood, N. and Jena, J. K. 2015. Establishment and characterisation of fin derived cell line from ornamental carp, Cyprinus carpio var. koi for virus isolation in India. In Vitro. Cell. Dev. Biol. Anim., 51(7): 705-713.

Swaminathan, T. R., Raj Kumar, Jency, P. M. E., Charan, R., Syamkrishnan, M. U., Basheer, V. S., Sood, N. and Jena, J. K. 2016. A new fish cell line derived from the caudal fin of freshwater angelfish Pterophyllum scalare: development and characterisation. J. Fish. Biol., 89(3): 1769-81.

Tamura, K., Peterson, D., Peterson, N., Stecher, G., Nei, M. and Kumar, S. 2011. MEGA5: Molecular evolutionary genetics analysis using maximum likelihood, evolutionary distance and maximum parsimony methods. Mol. Biol. Evol., 28(10): 2731-2739.

Tao, K., Yu, X., Liu, Y., Shi, G., Liu, S. and Hou, T. 2007. Cloning, expression and purification of insecticidal protein Pr596 from Locust pathogen Serratia marcescens HR-3. Curr. Microbiol., 55(3): 228-233.

Tariq, A. L. 2010. Molecular characterisation of Serratia marcescens; isolation of various origins pertaining protease, enzyme production, study on it's therapeutic and industrial applications. Ph. D. thesis, Peritar University, India. http://shodhganga.inflibnet.ac.in/handle/ 10603/20892

Wei, J. R. and Lai, H. C. 2006. N-Acylhomoserine lactonedependent cell to cell communication and social behavior in the genus Serratia. Int. J. Med. Microbiol., 296(2): 117-124. 
Weisburg, W. G., Barns, S. M., Pelletierand, D. A. and Lane, D. J. 1991. 16S ribosomal DNA amplification for phylogenetic study. J. Bacteriol., 173(2): 697-703.
Yu, V. L. 1979. Serratia marcescens. Historical perspective and clinical review. N. Engl. J. Med., 300(16): 887-893.

Date of Receipt : : 20.06.2017

Date of Acceptance : 06.10.2017 